Ujang Suryadi, Amal B dan Rosa Tri H, Penerapan Teknologi Pellet Pada Pakan Ayam Di UD.Kharisma Tunggal Jember

\title{
PENERAPAN TEKNOLOGI PELLET PADA PAKAN AYAM DI \\ UD. KHARISMA TUNGGAL JEMBER
}

Oleh :

Ujang Suryadi, Rosa Tri Hertamawati *) dan Amal Bahariawan **)

\begin{abstract}
ABSTRAK
Pakan berbentuk pellet merupakan hasil aplikasi teknologi terapan yang digunakan dalam pembuatan pakan dengan tujuan untuk meningkatkan kualitas dan efisiensi pakan. UD. Kharisma Tunggal sebagai pabrik pakan lokal yang berada di Jember, selama ini belum mampu menyediakan pakan berbentuk pellet karena alat dan penguasaan teknologi pembuatan pakan bentuk pellet belum dimiliki, tentunya hal ini memerlukan dukungan iptek.

Kegiatan penerapan teknologi Pelleter dapat mempercepat difusi dan manfaat Ipteks dalam meningkatkan kapasitas produksi dari segi kualitas dan kuantitas produk, mendorong berkembangnya budaya menerapkan inovasi teknologi pada pelaku usaha dalam memperbaiki kualitas produksi, dan akan menggerakan aspek manufaktur untuk selalu berinovasi dalam menciptakan teknologi terapan yang diperlukan oleh pengguna. Teraplikasikannya teknologi di dalam dunia usaha yang mendorong pengembangan berbagai inovasi teknologi untuk menjawab permasalahan yang ada pada industri pakan dalam meningkatkan efisiensi dan mengendalikan kualitas pakan.
\end{abstract}

Kata Kunci:, pelleter, pakan, ayam 
Ujang Suryadi, Amal B dan Rosa Tri H, Penerapan Teknologi Pellet Pada Pakan Ayam Di UD.Kharisma Tunggal Jember

\section{PENDAHULUAN}

Peningkatan kegiatan agribisnis peternakan berkolerasi positif terhadap peningkatan kebutuhan pakan ternak. Pendirian pabrik pakan lokal di daerah saat ini mendapat dukungan dari pemerintah. Pemerintah telah mengupayakan beberapa program terobosan yang mengarah kepada ketahanan pakan lokal, agar kedepan ketergantungan terhadap bahan impor dapat semakin berkurang dan pada akhirnya harapan untuk mandiri dengan menggunakan bahan baku pakan lokal dapat tercapai. Salah satu fasilitasi pemerintah dalam upaya pengembangan ketersediaan pakan lokal, adalah melalui pengembangan Unit Pengolah Pakan (UPP) Unggas.

Masalah utama kesediaan pakan ternak nasional adalah ketergantungan terhadap bahan pakan impor, sehingga apabila terjadi gejolak ekonomi ditingkat global atau regional, akan sangat mempengaruhi kinerja usaha peternakan. Penyediaan pakan yang murah, dari bahan pakan lokal yang tersedia secara terus menerus di sekitar tempat usaha budidaya serta dapat memenuhi kebutuhan gizi ternak, perlu diupayakan untuk memperoleh keuntungan yang maksimal dalam menunjang keberhasilan usaha budidaya yang dilakukan.

Pendirian pabrik pakan lokal di daerah sangat menjanjikan walaupun peternak (khususnya peternak ayam potong) ketika menyediakan pakan ayam pada umumnya telah bermitra dengan pengusaha agrinisnis multinasional, namun demikian masih ada peluang yang dapat digunakan untuk mengembangkan pabrik pakan lokal yaitu masih tersedianya sumber-sumber pakan seperti jagung yang tersebar di masyarakat dan tersediannya tepung ikan lokal yang selama ini belum sepenuhnya dikuasai oleh perusahaan besar, dengan demikian masih ada celah untuk mendirikan pabrik pakan ternak skala kecil (4 ton per hari) terutama untuk mamasok kebutuhan peternak lokal.

UD. Kharisma Tunggal merupakan salah satu pabrik pakan ternak lokal yang berlokasi di Kabupaten Jember. Pengembangan usaha pakan ternak yang dilakukan UD. Kharisma Tunggal cukup berhasil hal ini tercermin dari tingginya jumlah pakan yang dapat dipasok oleh perusahaan ke peternak lokal dan masih ada permintaan peternak yang belum dapat terpenuhi terutama pakan berbentuk crumble. Jumlah permintaan pakan ternak yang datang ke UD. Kharisma Tunggal sangat tinggi yaitu 100 ton untuk pakan ayam.

Peluang pasar pakan ternak ayam potong di wilayah Jember dan sekitarnya sangat berpotensi mengalami peningkatan, hal ini dapat di lihat dari adanya peningkatan populasi ayam potong dari tahun 2005 yaitu 896.784 ekor pada tahun 2009 mencapai 1,377 ekor (Jember dalam Angka 2010). Selain peningkatan populasi, fluktuasi harga pakan di tokotoko pakan ternak yang selalu mengalami kenaikan, belum terjamahnya penyediaan pakan untuk peternak kecil yang tidak bermitra dengan perusahaan besar dalam budidaya ayam potong merupakan prospek pendirian

Kualitas pakan unggas yang diproduksi oleh pabrik lokal belum mampu menyaingi produk pakan multinasional karena dihadapkan pada masalah rendahnya penguasaan teknologi diantaranya teknologi pembuatan pakan berbentuk pellet untuk pakan ayam potong. Pakan berbentuk pellet merupakan hasil aplikasi teknologi terapan yang digunakan dalam pembuatan pakan dengan tujuan untuk meningkatkan kualitas dan efisiensi pakan.

Saat ini peternak ayam potong yang pesan pakan ke UD Kharisma tunggal selalu meminta pakan ayam berbentuk pellet, kapasitas permitaan pakan tersebut per hari dapat mencapai \pm 4 ton. Adanya permintaan pakan berbentuk pellet telah memacu UD. Kharisma Tunggal sebagai pabrik pakan lokal untuk menyediakan pakan tersebut, sementara itu UD. Kharisma Tunggal saat ini belum memiliki mesin pembuatan pakan pellet. Selama ini pemenuhan permintaan pakan berbentuk pellet peternak ayam, UD. Kharisma Tunggal bekerjasama dengan Unit Pelayanan Teknis Pabrik Pakan Poltek Feed Indonesia dalam melakukan pembuatannya, namun demikian dalam kegiatannya menghadapi permasalahan yaitu adanya keterbatasan waktu yang disediakan oleh Poltek Feed Indonesia untuk pembuatan pellet yaitu hanya disediakan 2 hari dalam seminggu. Masalah lain yaitu perlu adanya penambahan biaya transportasi dari pabrik UD. Kharisma Tunggal ke Poltek Feed Indonesia sehingga tidak efisien. Besar biaya sewa yang dikeluarkan untuk proses pembuatan pellet ini mencapai Rp 500 per kg dan biaya transportasi Rp 50 per $\mathrm{kg}$, sehingga total biaya yang harus dikeluarkan untuk menghasilkan pakan bentuk pellet yaitu Rp 550 per kg. Permasalahan tersebut yang menjadi pembatas skala produksi pakan yang dilakukan oleh UD. Kharisma Tunggal.

UD. Kharisma Tunggal selama ini belum mampu menyediakan pakan berbentuk pellet karena alat dan penguasaan teknologi pembuatan pakan bentuk $\mathrm{n}$ pellet belum dimiliki, tentunya hal ini memerlukan dukungan iptek.

\section{METODOLOGI}

Aplikasi proses pelleting pada pembuatan pakan ayam potong agar memberikan manfaat dan tepat sasaran, maka kegiatan ini dilakukan dengan metode:

1) Introduksi pembuatan alat pelleter

2) Pendampingan dan pembimbingan oprasional alat

3) Monitoring dan Evaluasi

\section{Tahapan kegiatan}




\section{1) Introduksi Pembuatan Alat}

\section{a. Perencanaan}

Perencanaan perancangan alat pelleter. Pada tahap ini dilakukan sosialisasi dan temu kerja antara pelaksana dan mitra untuk merumuskan perancangan alat pelleter, sesuai dengan target produksi yang akan dipenuhi.

b. Uji unjuk kerja alat di lab

Uji unjuk kerja alat pellet dilakukan untuk menilai kesesuai dan kemampuan peralatan dengan spesifikasi produk pellet yang dihasilkan, bila tidak sesuai maka dirancang ulang.

c. Uji coba produksi.

Uji coba alat pellet dilakukan untuk menilai kemampuan peralatan dalam proses produksi.

2) Pendampingan dan pembimbingan proses produksi pembuatan pelleting

Pendampingan dan pembimbingan dilakukan agar pekerja dapat menggunakan mesin dengan benar, mampu melakukan perawatan, dan aman (ergonomis). Selain itu untuk mengembangkan mekanisme alih teknologi dalam proses produksi pembuatan pelleting agar kegiatan berhasil secara maksimal.

\section{3) Monitoring dan Evaluasi kegiatan}

a. Evaluasi dan monitoring kegiatan dilakukan untuk memantau kemajuan pemanfaatan iptek pembuatan pakan ternak, melakukan inventarisasi teknologi yang diterapkan, melaporkan kemajuan kegiatan, hambatan, atu penyimpangan yang terjadi, dan memberi masukan kebijakan berkaitan dengan kegiatan yang ditangani.

\section{HASIL DAN PEMBAHASAN}

Survey lapang ketika akan melakukan kegiatan merupakan suatu upaya yang perlu dilaksanakan untuk mengevaluasi kembali kesesuai rencana kerja yang tertulis di dalam proposal dengan kondisi saat akan dimulai kegiatan. Survey lapang memberikan gambaran tentang kemantapan tujuan dan sasaran yang telah ditetapkan dalam proposal.

Penerapan prinsip penelitian kaji tindak diperlukan upaya; pengenalan masalah, perumusan masalah dan penetapan prioritas, identifikasi alternatifalternatif pemecahan masalah/pengembangan gagasan. Masalah yang telah ditetapkan dibahas dengan urun rembuk antara peneliti dan mitra. Penyelesaian masalah dilakukan melalui perencanaan kegiatan; yang selanjutnya dituangkan ke dalam sebuah rencana kegiatan yang konkrit. Rencana memuat dengan jelas jenis kegiatan yang akan dilakukan, siapa yang akan melakukannya, dan kapan waktu pelaksanaannya. Pelaksanaan kegiatan tidak mengalami hambatan yang berarti, karena semua kegiatan telah direncanakan dengan baik.

Perancangan Mesin Pellet
Mesin pellet adalah mesin / alat pembentukan bahan pakan menjadi berbentuk pellet dengan cara diberi tekanan / kompresi dan dilewatkan melalui lubang-lubang yang terdapat pada silinder die. Mesin pellet terdiri dari hooper, screw feeder, dies, roller, gear box, stam nozzle, fat sprayer, motor penggerak.


Gambar 1. Prinsip kerja pellet

\section{Hooper}

Hooper berfungsi untuk menampung makanan sementara dari tong pellet tersebut, bahan akan dilahirkan conditioner melalui screw feeder dengan dry flow yang feed ratenya telah diatur (ton/jam).

\section{Screw feeder}

Screw feeder berfungsi untuk membawa makanan (mash) dari hooper masuk kedalam conditioner atas dan conditioner bawah. Screw feeder berbentuk screw yang dapat membawa makanan terbawa ke bagian conditioner. Pengoperasian mesin pellet sendiri dioperasikan oleh seorang operator mesin. Dari screw feeder bahan pakan dibawa dengan feeder speed yang telah diatur kecepatannya (\%).

\section{Roller}

Roller adalah alat yang berfungsi untuk mengolah bahan baku dengan cara menggiling pada bagian dalam die agar bahan baku tersebut mask ke dalam die untuk proses pembentukan pellet. Permukaan luarnya berbentuk seperti roda gigi yang berfungsi menekan makanan masuk kedalam lubang die. Dari conditioner, makanan masuk kedalam dies dan ditekan masuk kedalam lubang-lubang dies dan ditekan masuk kedalam lubang-lubang dies dengan tekanan dari roller.

\section{Die}

Die adalah alat yang terdapat dalam mesin pellet dan berfungsi untuk membentuk makanan menjadi butiran pellet dengan bantuan dari roller. Tiap mesin pellet memakai die dengan tipe dan spesifikasi berbeda-beda, 
Ujang Suryadi, Amal B dan Rosa Tri H, Penerapan Teknologi Pellet Pada Pakan Ayam Di UD.Kharisma Tunggal Jember

baik dari ketebalan lubang dies, diameter dies dan jumlah lubang dies yang berkisar antara 14.000 sampai 17.000 lubang. Die diputar oleh poros motor penggerak dengan daya yang besar, sedangkan roller berputar menekan makanan masuk die karena permukaan luarnya berhimpitan dengan makanan masuk kedalam lubang die.

\section{Pisau pellet}

Pisau pellet adalah alat untuk memotong pellet yang keluar dari lubang-lubang die. Pada saat pellet keluar dari lubang die dan telah di fat spray / tidak, pellet akan dipotong oleh pisau potong dengan ukuran yang telah diatur panjang pemotongannya sesuai standar ukuran pellet dengan panjang $0,5-0,6 \mathrm{~cm}$.

Pellet yang keluar dari mesin pellet memiliki panas > $80^{\circ} \mathrm{C}$. Hal ini sesuai dengan teori yang menyatakan bahwa suhu yang diperlukan untuk dapat terjadinya gelatinisasi adalah antara $80^{\circ} \mathrm{C}$ sampai $90^{\circ} \mathrm{C}$, sehingga dapat kita perkiraan bahwa pellet yang terbentuk telah mengalami gelatinisasi. Pellet yang telah dibentuk kemudian keluar dari mesin pellet dan dialirkan turun kedalam mesin pendingin (cooler) melalui pipa-pipa penghubung mesin pellet dengan mesin cooler.

\section{Pembuatan Mesin Pellet}

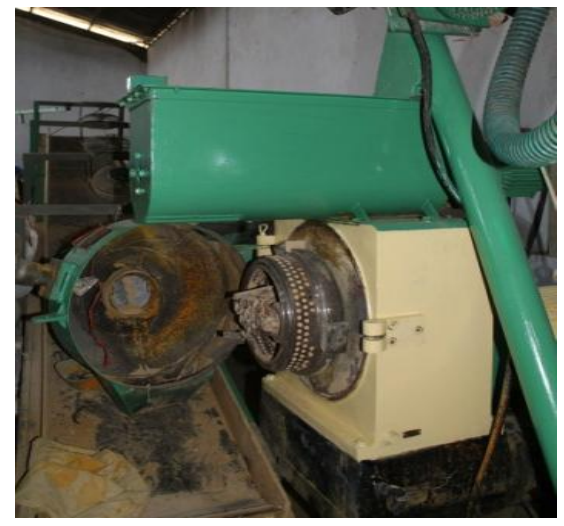

Gambar 2. Mesin Pellet

Pakan berbentuk pellet merupakan produk hasil pembuatan pakan dengan melibatkan tekanan dan kelembaban. Proses pelleting adalah proses penggumpalan bahan berbentuk partikel-partikel berukuran kecil (mash) dibentuk menjadi partikelpartikel yang lebih besar (pellet/crumble) melalui proses mekanik yang dikombinasikan dengan faktor tekanan, panas dan kelembaban.

Patrick dan Schaible (1980) menjelaskan keuntungan pakan bentuk pelet adalah meningkatkan konsumsi dan efisiensi pakan, meningkatkan kadar energi metabolis pakan, membunuh bakteri patogen, menurunkan jumlah pakan yang tercecer, memperpanjang lama penyimpanan, menjamin keseimbangan zat-zat nutrisi pakan dan mencegah oksidasi vitamin. Proses pengolahan pellet menurut Pujaningsih (2006) memiliki tujuan dan keuntungan yaitu :

1. Meningkatkan karateristik pakan

2. Menurunkan segregasi bahan pakan

3. Meningkatkan manfaat gizi pakan

4. Menurunkan jumlah eneri yang dibutuhkan untuk mengkonsumsi pakan

5. Menurunkan dan menghilangkan mikroorganisme pathogen

6. Meningkatkan densitas pakan

7. Menurunkan kehilangan pakan yang berbentuk mash

Uji coba alat pelleter memberikan dampak terhadap kualitas pellet yang dihasilkan. Kualitas pellet yang yang dihasilkan memiliki tekstur yang kompak sehingga jumlah pellet yang hancur dan berbentuk utuh memiliki proporsi yang banyak

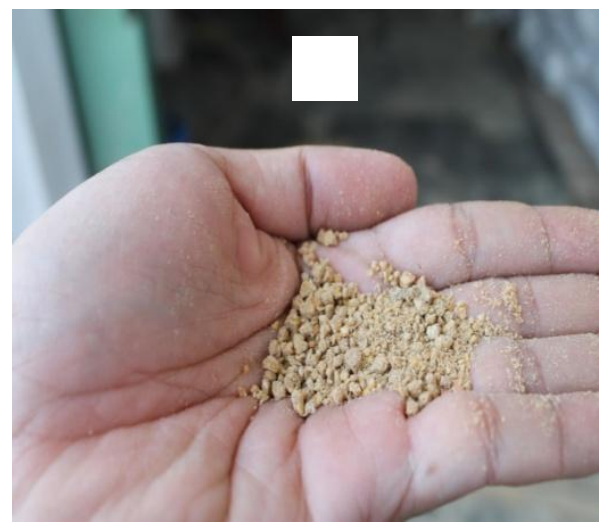

Gambar 3. pellet yang dihasilkan

Kegiatan pendampingan dan pembimbingan proses produksi pembuatan pelleting yang dilakukan di Pabrik pakan UD "Kharisma Tunggal" memberikan dampak terhadap produktivitas pabrik dan kualitas pellet yang dihasilkan. Pabrik pakan UD "Kharisma Tunggal" saat ini telah mampu memprodukasi pakan berbentuk pellet yang sebelumnya tidak dapat diproduksi. Deversifikasi pakan berbentuk pellet telah menambah jumlah produksi dan membuka pasaran baru.

Tabel 1. Penjualan Pakan Pellet dari Bulan Juli September 2014

\begin{tabular}{|c|c|c|c|}
\hline $\begin{array}{c}\text { Tanggal } \\
\text { Pengiriman }\end{array}$ & $\begin{array}{c}\text { Jenis } \\
\text { Pakan }\end{array}$ & Jumlah & $\begin{array}{l}\text { Alamat } \\
\text { Tujuan }\end{array}$ \\
\hline 08-08-2014 & $\begin{array}{l}\text { Pakan } \\
\text { Finisher }\end{array}$ & 7,5 ton & $\begin{array}{l}\text { Pt. Baling- } \\
\text { baling }\end{array}$ \\
\hline
\end{tabular}


Ujang Suryadi, Amal B dan Rosa Tri H, Penerapan Teknologi Pellet Pada Pakan Ayam Di UD.Kharisma Tunggal Jember

\begin{tabular}{|l|l|l|l|}
\hline & (pellet) & & $\begin{array}{l}\text { Bambu } \\
\text { Jl. } \\
\text { Brawijaya- } \\
\text { Mataram }\end{array}$ \\
\hline 13-08-2014 & $\begin{array}{l}\text { Pakan } \\
\text { Finisher } \\
\text { (pellet) }\end{array}$ & 7,5 ton & $\begin{array}{l}\text { Pt. Baling- } \\
\text { baling } \\
\text { Bambu } \\
\text { Jl. } \\
\text { Brawijaya- } \\
\text { Mataram }\end{array}$ \\
\hline 17-08-2014 & $\begin{array}{l}\text { Pakan } \\
\text { Finisher } \\
\text { (pellet) }\end{array}$ & 7,5 ton & $\begin{array}{l}\text { Pt. Baling- } \\
\text { baling } \\
\text { Bambu } \\
\text { Jl. } \\
\text { Brawijaya- } \\
\text { Mataram }\end{array}$ \\
\hline 26-08-2014 & $\begin{array}{l}\text { Pakan } \\
\text { Finisher } \\
\text { (pellet) }\end{array}$ & 7,5 ton & $\begin{array}{l}\text { Pt. Baling- } \\
\text { baling } \\
\text { Bambu }\end{array}$ \\
& & & $\begin{array}{l}\text { Jl. } \\
\text { Brawijaya- } \\
\text { Mataram }\end{array}$ \\
\hline
\end{tabular}

\section{KESIMPULAN DAN SARAN \\ Kesimpulan}

Dari hasil penelitian Ristek DF di Pabrik pakan

UD. Kharisma dapat disimpulkan yaitu;

1) Teradopsinya teknologi manufaktur pellet pada pabrik pakan lokal,

2) Bertambahnya ilmu pegetahuan dan teknologi yang dikuasai mitra di dalam memproduksi pakan ayam,

3) Terjadinya pengembangan inovasi teknologi dalam pengolahan pakan, meningkatkan kualitas dan efisiensi pakan,

4) Terjadinya peningkatan kapasitas produksi dan jenis produk pakan (diversivikasi produk) yang dihasilkan oleh mitra, dan

5) Permintaan peternak ayam potong terhadap pakan berbentuk pellet yang murah dengan kualitas pakan yang memenuhi standar SNI dapat terpenuhi, terutama bagi peternak ayam di wilayah Jember dan sekitar yang tidak menjalin kemitraan dengan pengusaha perunggasan besar.

\section{DAFTAR PUSTAKA}

American Societ for Agricultural Enginner. 1997. Cubes, Pellets and Crumbles-definition and Methode for Determining Density, durability, and Moisture. Am. Soc. Agric. Eng.

Behnke. K.C. 1994. Factor Affecting Pellet Quality. Maryland Nutrition Conference. Dept. Of Poultry Science and Animal Science. University of Maryland.

Dozier. W.A. 2001. Kualitas pellet pakan unggas pedaging (terhubung berkala). http://www. alabio.cjb.net. (5 Juli 2009).

Karsidi, Ravik (2001).Paradigma Baru Penyuluhan Pembangunan dalam Pemberdayaan Masyarakat. Dalam Pambudy dan A.K.Adhy (ed.): Pemberdayaan Sumberdaya Manusia Menuju Terwujudnya Masyarakat Madani, Bogor: Penerbit Pustaka Wirausaha Muda.

Khalil. 1999. Pengaruh Kandungan Air dan Ukuran Partikel Terhadap Sifat Fisik Pakan Lokal: Kerapatan tumpukan, Kerapatan pemadatan tumpukan dan berat jenis. Media Peternakan 22 (1): $1-11$.

Hartadi. H., S. Reksodiprojo dan A.D. Tillman. 1990. Tabel Komposisi Pakan untuk Indonesia. Gadjah Mada University Press,. Yogyakarta.

Mc. Ellhiary. R.R. 1994. Feed Manufacturing Technology IV. Am. Feed Industry Assoc. Inc. Arlington

Misra, C.K., N.P. Sahu dan K.K. Jain. 2002. Effect of extrusion processing and steam peleting diets on pelet durability, water absorption and physical response of Macrobrachium rosenbergii. Asian-Aust. J. Anim. Sci. 15(9): $1354-1358$

Pujiningsih, R.I. 2006. Pengelolaan Pakan Bijian. Cetakan 1. Penerbit Alif Press. Semarang 